\section{Sturge-Weber-Crabbe Syndrome (review and portfolio)}

L.R. Zabudskaya, L.S. Vigovskaya, K.O. Ruzhylo

Pechersk District Children's Clinical Hospital No. 7, Kiev, Ukraine
Sturge-Weber-Crabbe syndrome (SWCS, encephalo-trigeminal angiomatosis) is a rare neurocutaneous disease (phakomatosis) characterized by vascular skin, eyes and brain abnormalities. Phakomatoses are a group of hereditary progressive diseases with combined damage of the nervous system, skin, eyes and internal organs as a result of impaired neuronal proliferation in the process of neuroontogenesis [1]. The incidence is 1 for 50,000 , equally often in women and men. All races and ethnic groups without gender distinction are affected. In most of the published observations, the age of patients is from 10 to 20 years, that proves the increased syndrome frequency among elder children and young adults $[1,3,4,9]$.

First diagnosed clinical case of SWCS [3] in a 20 -year-old pregnant woman, manifested by congenital unilateral angioma in the innervation zone of the I and II branches of the trigeminal nerve, neuropathy of the facial nerve, polymorphic epilepsy with solitary epileptic tonic-clonic attacks with retrograde amnesia, absences, mild mental retardation is described.

The syndrome has many synonyms: "SturgeWeber syndrome" (most often applied in the literature) "Weber syndrome", "Sturge-Weber-Dimitri syndrome", "Weber-Dimitri syndrome", "Sturge syndrome", "Kallischer syndrome", "Krabbe syndrome", "Sturge-Weber-Krabbe-Brushfield-Wyatt syndrome", "Lawford syndrome", "Schirmer syndrome", "Milles syndrome", "congenital neuroectodermal dysplasia", "congenital ectodermosis", "cutaneous cerebral angioma", "encephalofacial neuroangiomatosis", "encephalo-trigeminal angiomatosis", "angiomatosis of the meninges, eyes and face". These and other atypical variants of the disease are currently considered outdated terms and present only historical interest [1, 4-7].

Historical reference. The first publication on the syndrome belongs to the German ophthalmologist R. Schirmer (1831-1896): he described a male patient with a facial nevus and buphthalmos in 1860, but did not admit that it was a neurological condition. English physician and archaeologist W.A. Sturge (1850-1919) in 1879 described this disease in a six-year-old child [12]. In 1922, the English dermatologist F.P. Weber (1863-1962) reported the first X-ray signs of cerebral atrophy and intracranial calcification at this disease [15] (4 more different diseases are named after Dr. Weber!). The final division into an independent nosology belongs to the Danish neurologist K.N. Crabbe (1934). It should be noted that the Austrian dermatologist V. Dimitriy (1885-1955), the German neuropathologist Z. Kalischer (18621954) and other clinicians participated in the detailing and description of the heterogeneity of the syndrome symptomatology [1].

Etiopathogenesis - is insufficiently studied. In $80 \%$ of patients (as in the case of isolated flaming nevus), somatic mutations of the GNAQ gene encoding a guanine nucleotide, which is involved in the regulation of cellular effectors, were identified. It is assumed that mutant proteins interrupt vasculogenesis at an early stage of embryonic development (in patients at histological studies in the angiomatosis zones, the residual embryonic blood vessels with violation of their structure, innervation and function, which cause secondary effects on the surrounding tissues are found). Mutations of other genes are also possible $[8,13]$.

Somatic genetic mosaicism, in which some of the cells of human tissues have a causal genetic mutation, while others do not, that is, they are "healthy" is characteristic. Depending on which cells are more (with or without mutation), the severity of the disease varies, as well as its progression rate in different patients $[1,3]$.

A significant role in the pathogenesis belongs to impaired blood flow and sometimes to prenatal deep venous thromboocclusion in the brain tissues [12].

The heredity of the syndrome has not yet been clearly proven, but several observations demonstrate uneven dominant transmission. 
Clinical cause. SWCS is a sporadically occurring disease with angiomas of the pia mater and facial skin, usually in the ophthalmic and maxillary branches of the trigeminal nerve. The pia mater lesion may be unilateral and bilateral. It is often accompanied by neurological and mental disorders in the form of hemiparesis, hemianopsia, mental retardation, attention and hyperactivity deficit syndrome, and epilepsy [5-7].

SWCS is characterized by the classic triad of symptoms (angiomatosis of the face, meninges, glaucoma, and seizures). However, this classic triad of symptoms occurs in about $20 \%$ of cases; mono- and bisymptomatic forms of this pathology are observed more often $[1,4,7]$.

3 types of SWCS are distinguished: angiomas of the face and pia mater, may be glaucoma; only facial angiomas, without damage to the central nervous system, may be glaucoma; only pia mater angiomas, usually without glaucoma.

The classic complex of symptoms of SWCS includes the Krabbe triad: flaming nevi along the branches of the trigeminal nerve, intracranial calcifications, symptomatic focal epilepsy $[1,14]$.

Diagnostics [2, 5, 7, 9]. MR and SCT angiography of cerebral arteries, veins and sinuses are used in children and adults to determine the failure of superficial cortical veins, empty dural sinuses, pathological deformation of the veins; brain CT (preferably multislice spiral computed tomography - MSCT) - intracerebral calcifications, a symptom of "tram rails", cortical atrophy, abnormal expansion of the venous network of the choroidal plexuses of the lateral ventricles; brain MRI (preferably MRI with gadolinium) - expansion of the choroidal plexuses, occlusion of the venous sinuses, cortical atrophy, brain demyelination of dystrophic genesis; single-photon emission computed tomography (SPECT) - the brain substance hyperperfusion areas (in the early stages of the disease), the brain hypoperfusion areas (in the later stages of the disease); positron emission tomography (PET) - the brain hypometabolism areas; video EEG monitoring - a decrease in the power of the brain bioelectrical activity, polyfocal epileptiform activity, represented mainly by paroxysms of high-amplitude theta and delta waves [3].

The basal ganglia calcification is a group of pathological syndromes. The main diagnostic feature: bilateral calcification of the basal ganglia, dentate cerebellar nuclei and other areas of the brain [2]. Symmetrical calcification of the basal ganglia of various sizes, shapes and locations is also observed at SWCS.

Verification of the basal ganglia calcification was, as a rule, based on a retrospective analysis of clinical and laboratory data: the diagnosis is based on the results of postmortem examination. With the advent and prevalence of the brain CT investigation, the frequency of basal ganglia calcification detection has increased [2].

Clinical observation. Patient Anastasia O., 9 years. Diagnosis: SWCS (Fig. 1). The results of $\mathrm{CT}$ and MRI investigations are presented in Figures 2-24.

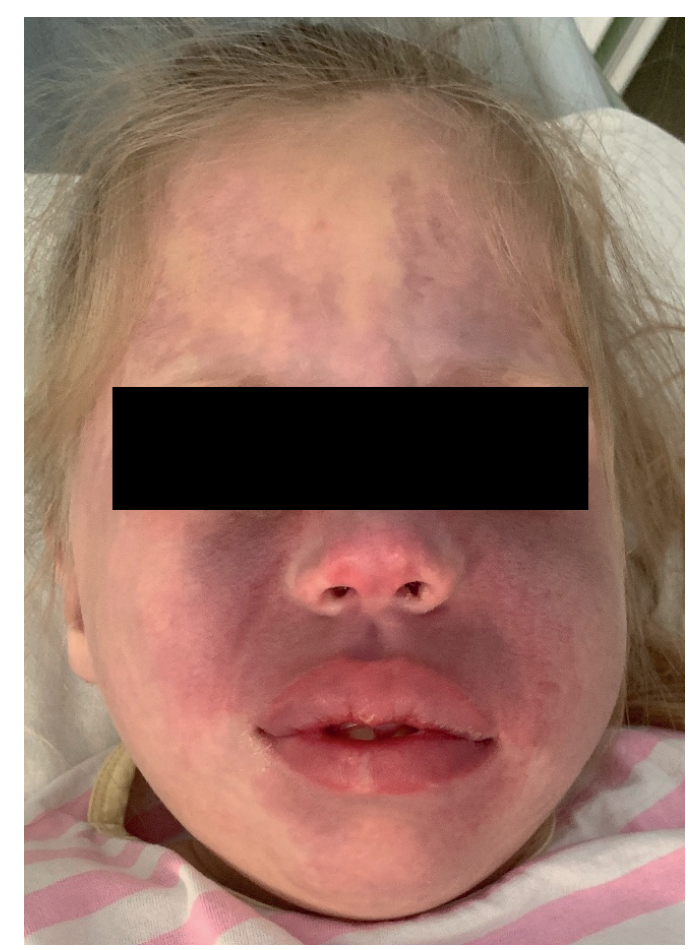

Fig. 1. The appearance of the patient with SWCS. Cutaneous angiomatosis.

Evolution and prognosis of SWCS - depends on the prevalence of brain damage. Usually the prognosis is poor due to frequent and severe neurological complications. Patients with SWCS should be under observation by a multidisciplinary team of doctors trained in the diagnostics and treatment of hereditary neurocutaneous syndromes - medical geneticist (neurogeneticist), dermatologist, neurologist, epileptologist, neurosurgeon, neuropsychologist (psychologist), ophthalmologist (ophthalmic surgeon), vascular surgeon, neuroradiologist [3]. The SWCS prognosis is very variable. 


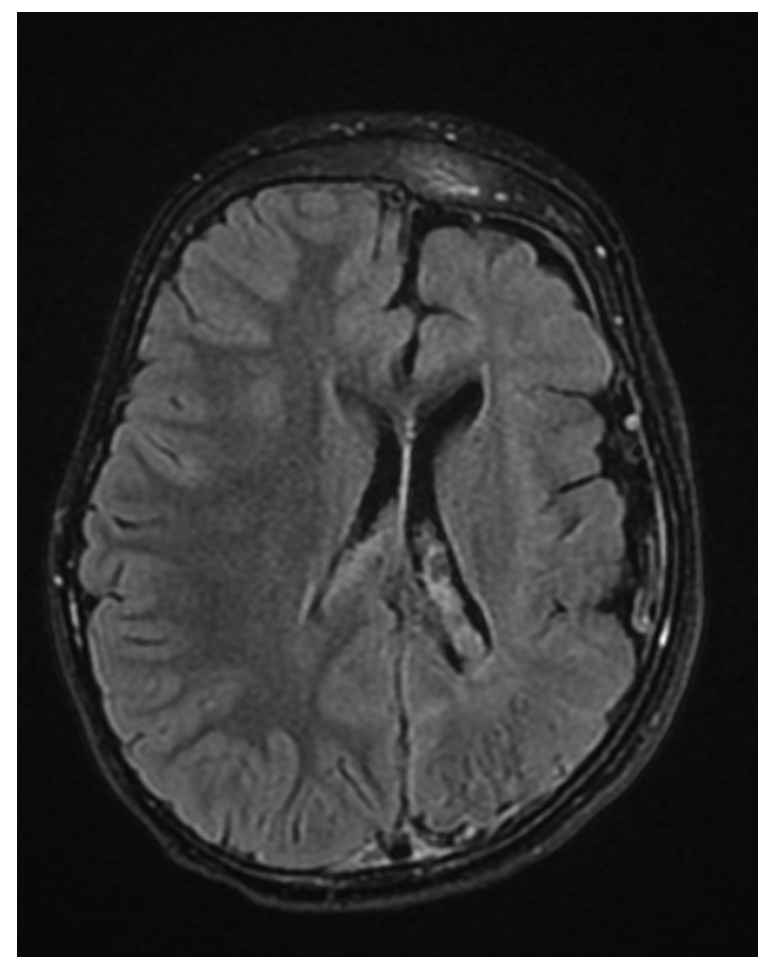

Fig. 2. $A X$ T2 FLAIR. Asymmetry with a decrease in the volume of the brain left hemisphere. Hypertrophy of the choroid plexus of the left lateral ventricle.

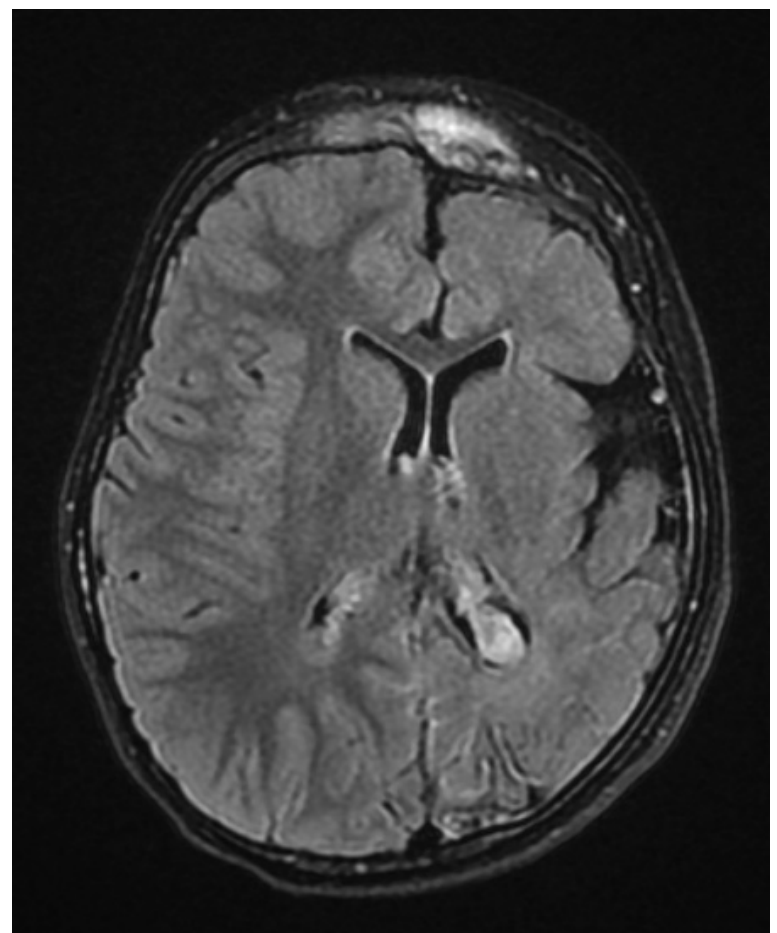

Fig. 3. $A X$ T2 FLAIR. Asymmetry with a decrease in the volume of the brain left hemisphere. Hypertrophy of the choroid plexus of the left lateral ventricle. The local signal increase from the frontal bone (without osteo-pathological changes on CT) is reliably vascular.

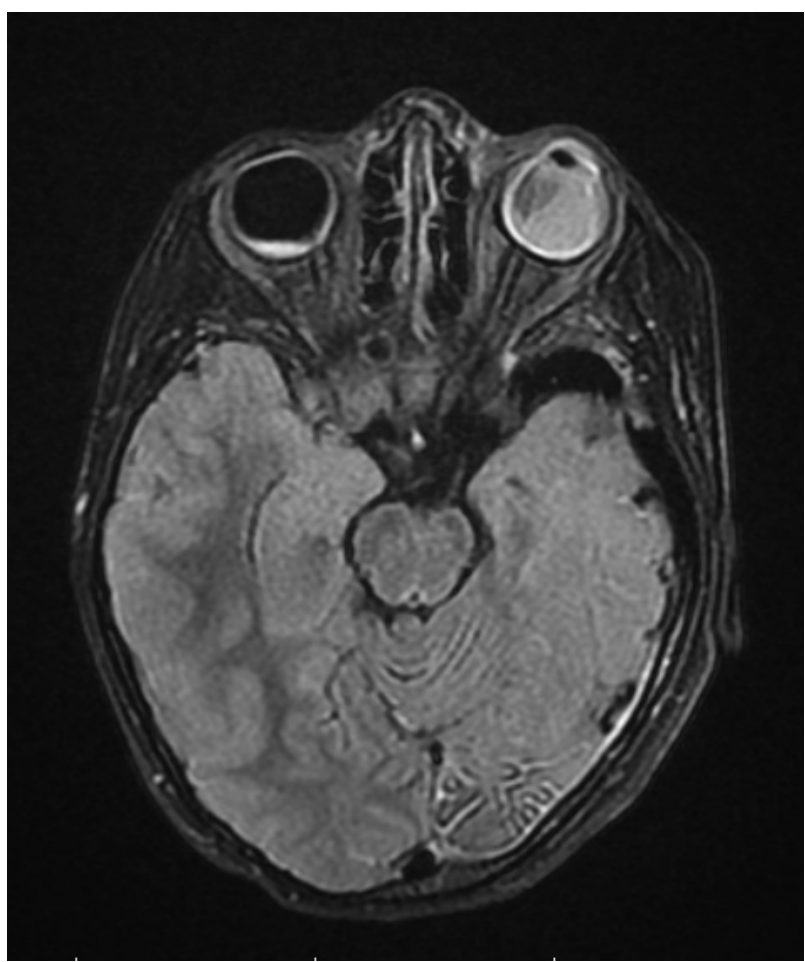

Fig. 4. AXT2 FLAIR. Asymmetry of the brain hemispheres with a decrease in the volume of the left and thinning of the individual gyri. Choroidal angioma on the right and more pronounced angiomatous changes in the left eyeball with the spread of the process to the vitreous body and deformation of the lens.

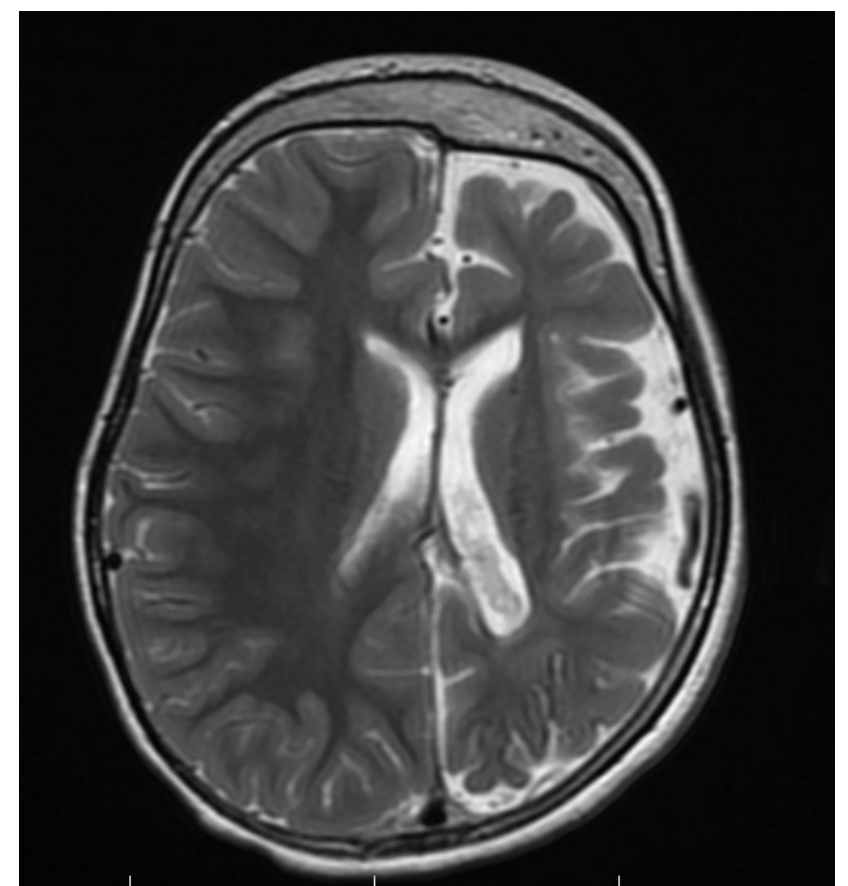

Fig. 5. AXT2 WI. Asymmetry of the brain hemispheres with a decrease in the volume of the left, thinning of the most of gyri and a rim of reduced intensity in the cortical regions. Hypertrophy of the choroid plexus of the left lateral ventricle. 


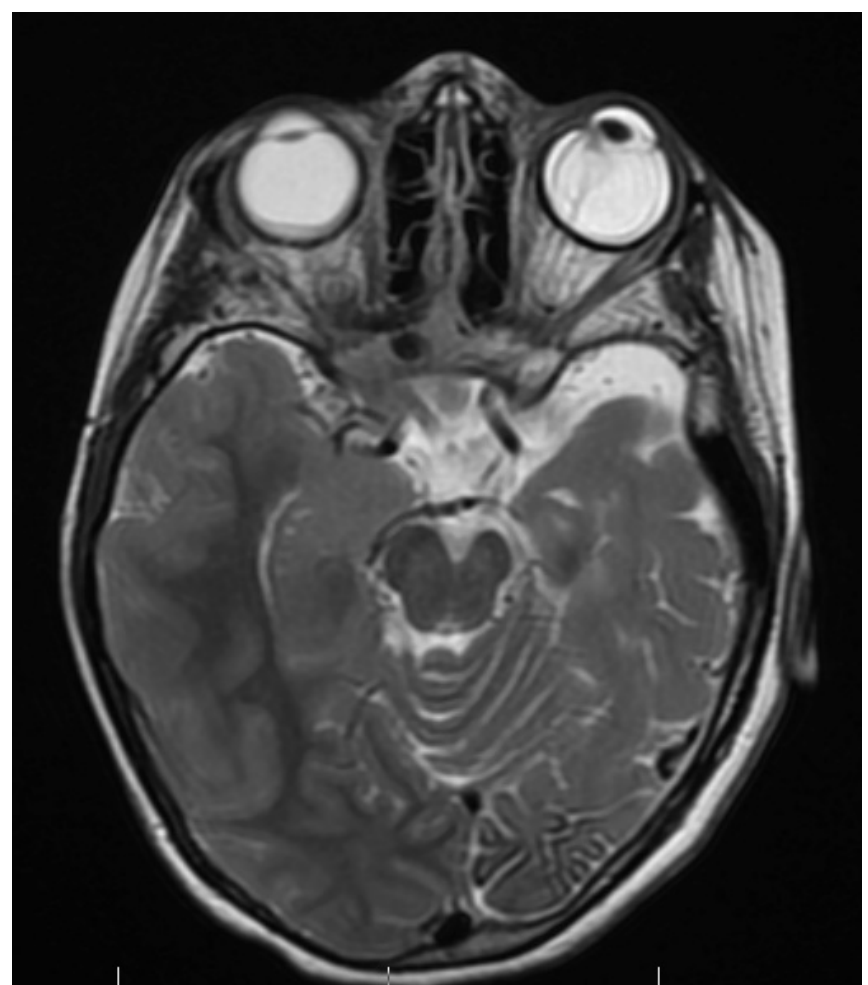

Fig. 6. AXT2 WI. Asymmetry of the brain hemispheres with a decrease in the volume of the left, thinning of the most of gyri and a rim of reduced intensity in certain cortical regions. Signs of choroidal angiomas, on the left with a greater severity of the process in the form of spread to the vitreous body and deformation of the lens.

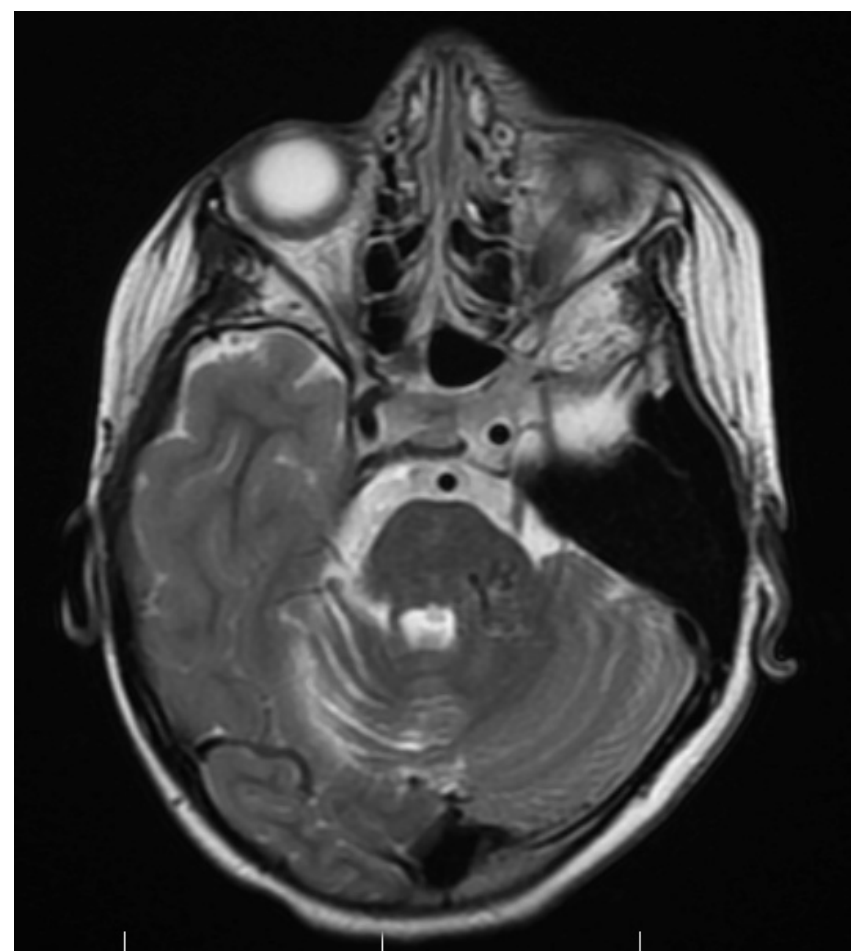

Fig. 7. AX T2 WI. Asymmetry of brain hemispheres. AVM of the left middle cerebellar peduncle.

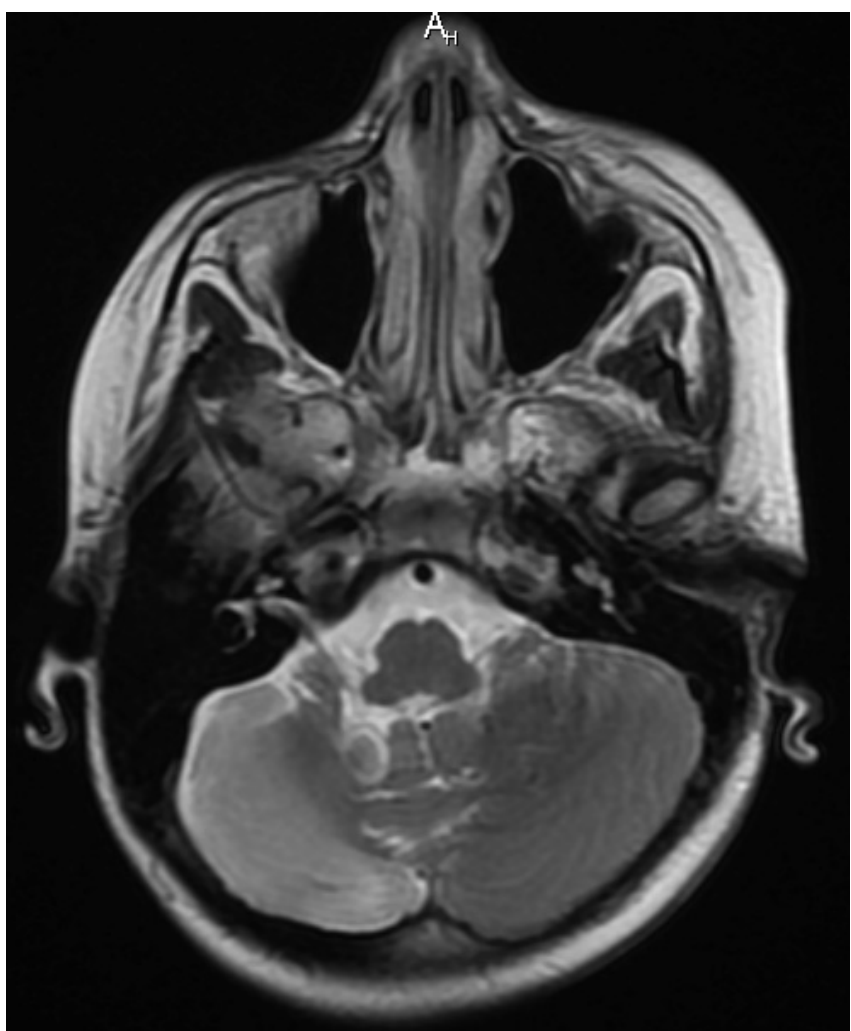

Fig. 8. $A X T 2$ WI. Hypoplasia of the right cerebellar hemisphere with diffuse changes of the MR signal.

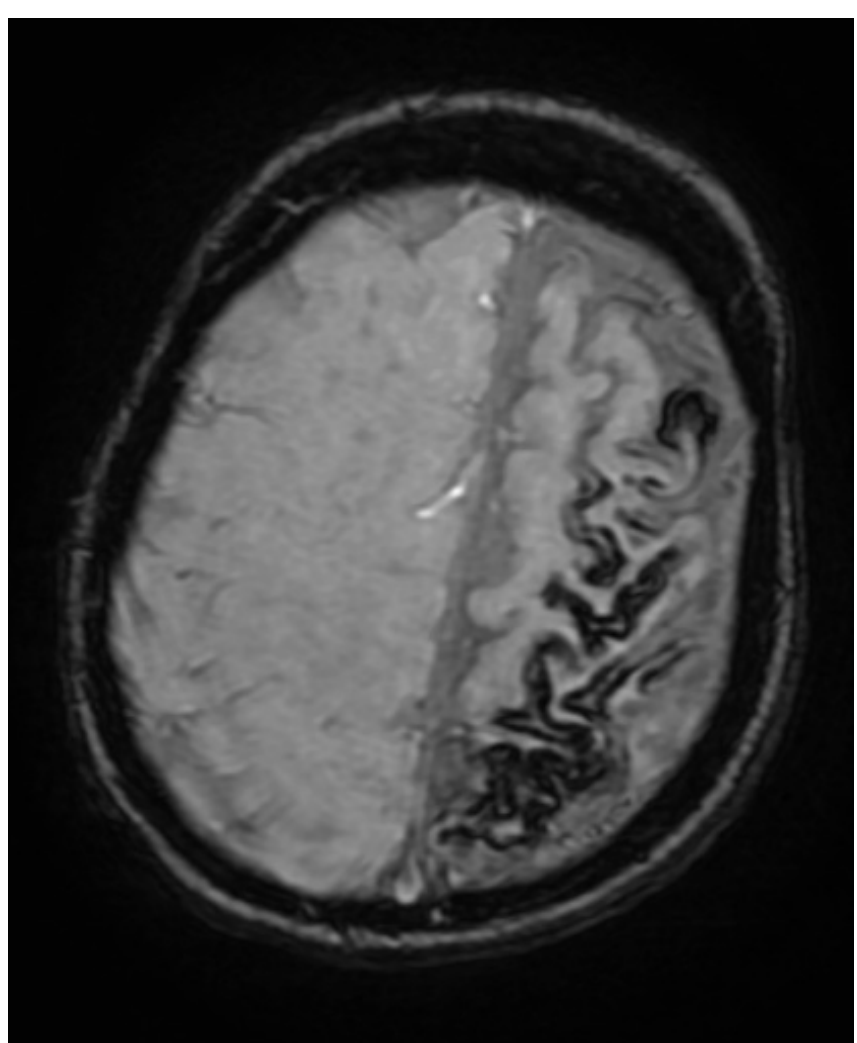

Fig. 9. AX SWAN. Diffuse areas of signal loss in the cortical regions of the left brain hemisphere, corresponding to the calcification areas. 


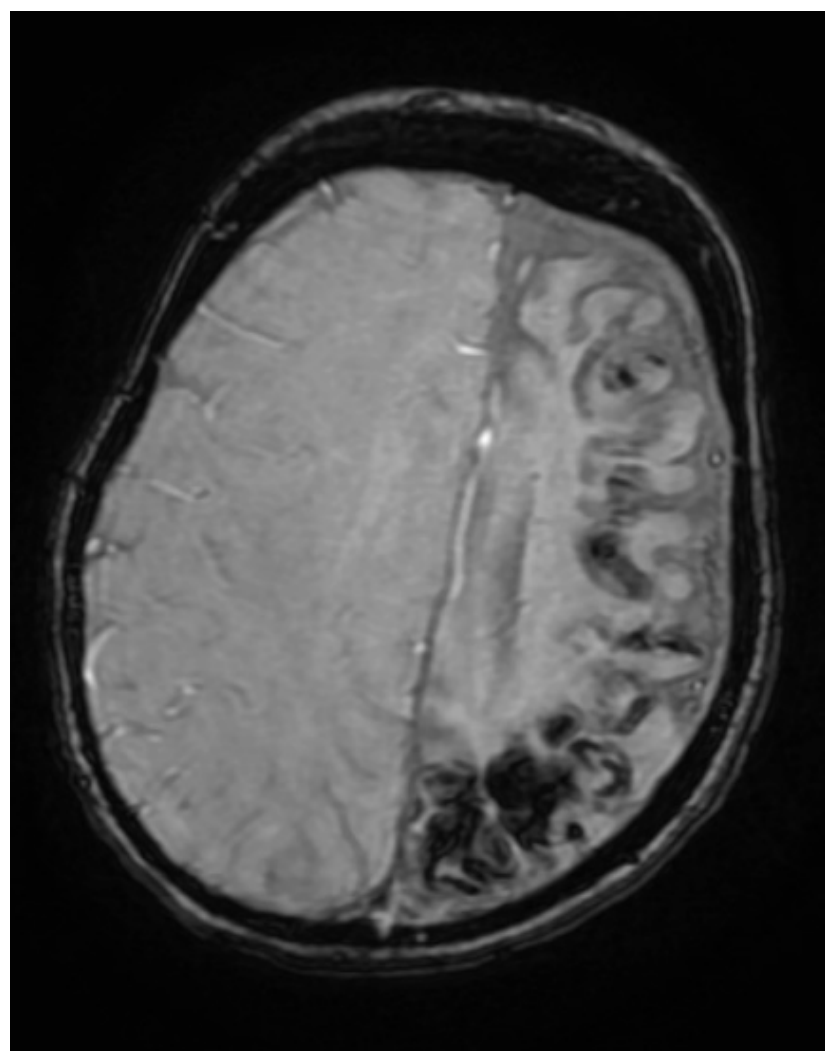

Fig. 10. $A X S W A N$. The same.

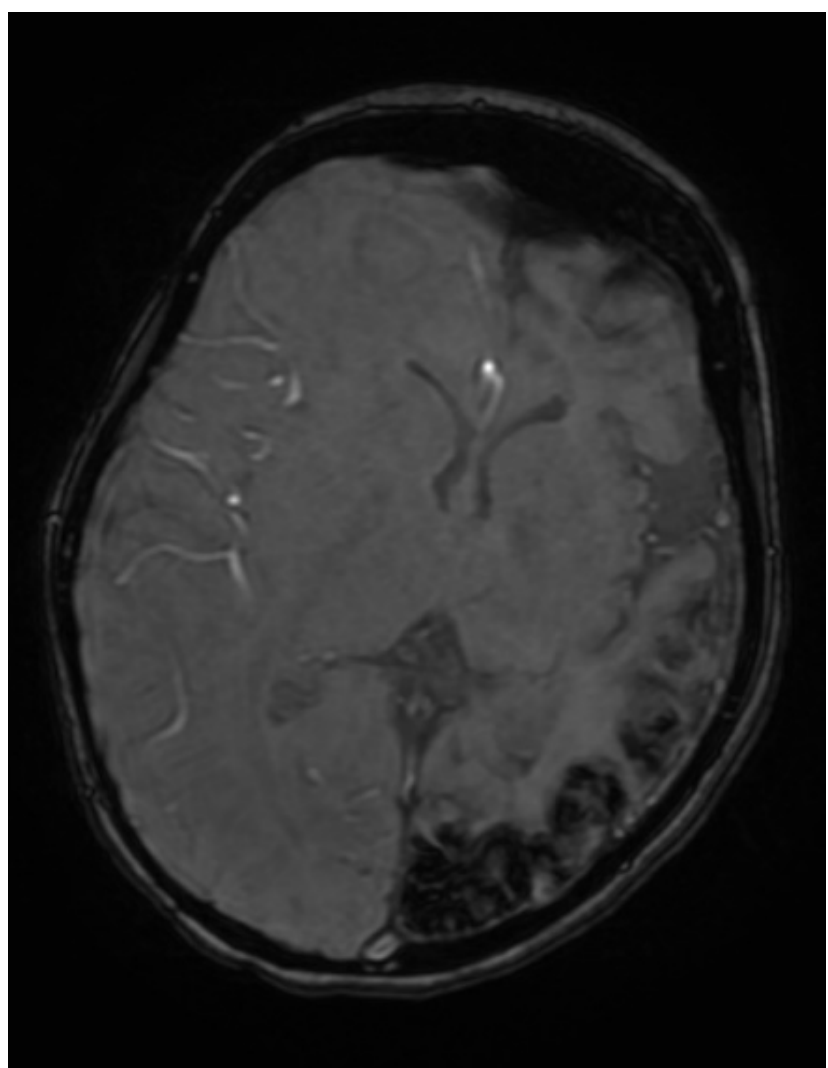

Fig. 11. AX SWAN. Diffuse areas of signal loss in the cortical and subcortical parts of the left brain hemisphere, corresponding to areas of calcification.

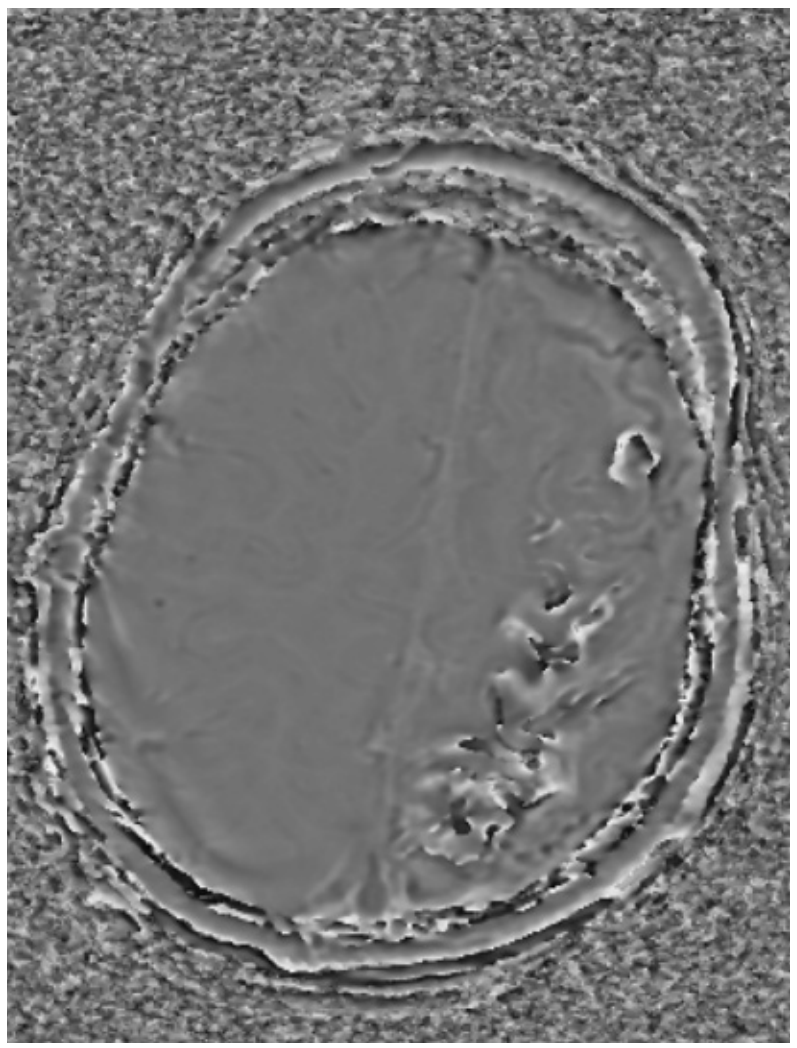

Fig. 12. AX SWAN FILT-PHASE. Areas of the altered signal in the cortical regions of the left brain hemisphere, corresponding to calcification areas.

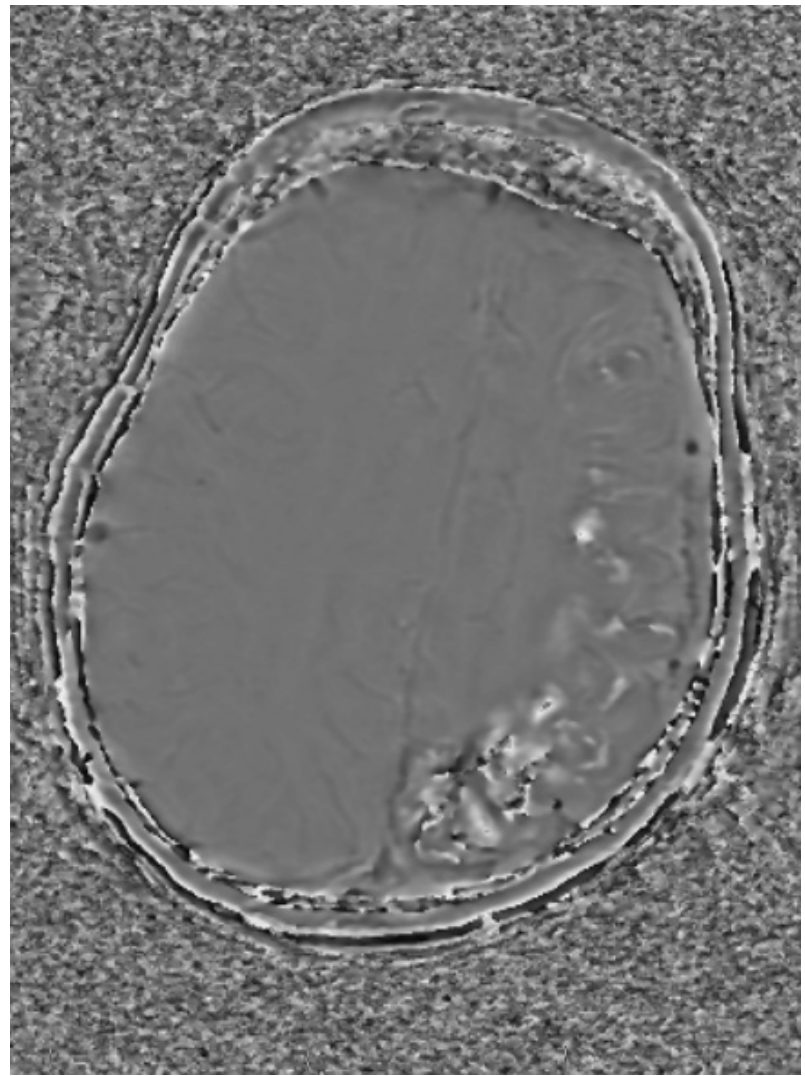

Fig. 13. AX SWAN FILT-PHASE. The same. 


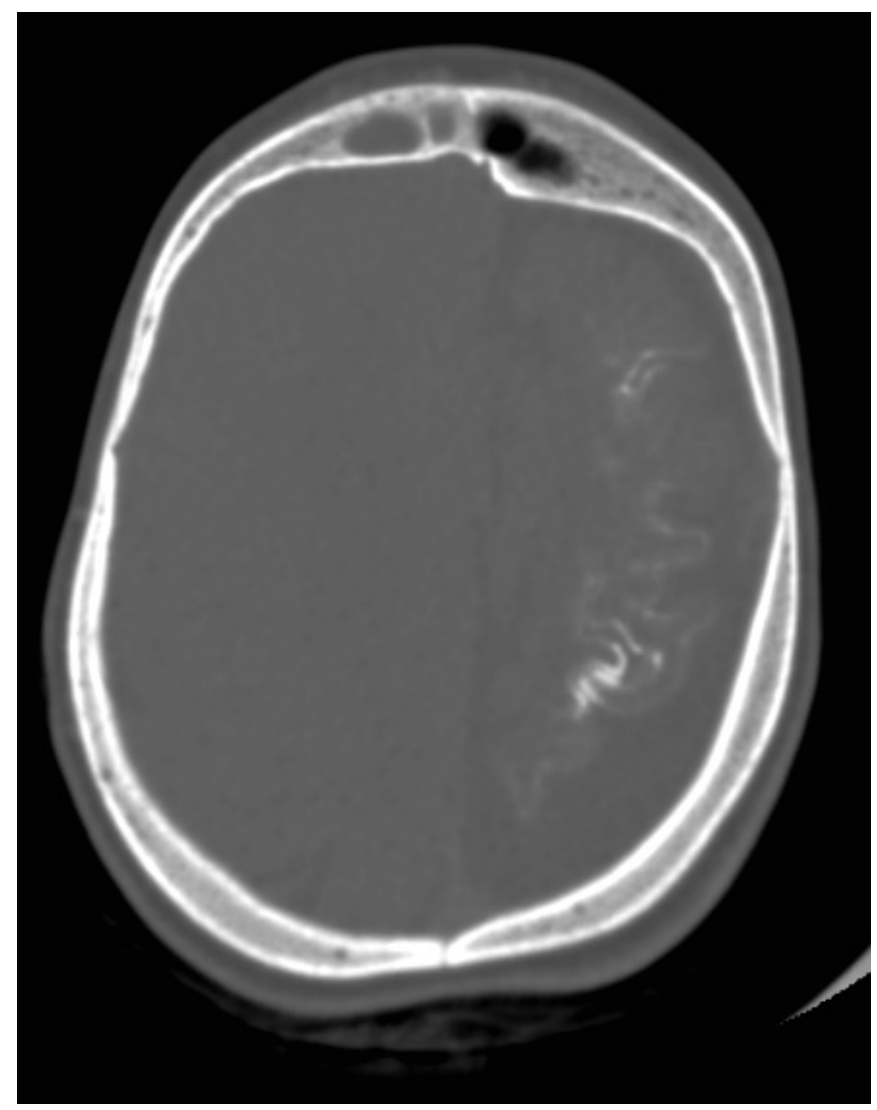

Fig. 14. Non-contrast brain CT (bone mode). Multiple areas of gyral calcification in the left brain hemisphere.

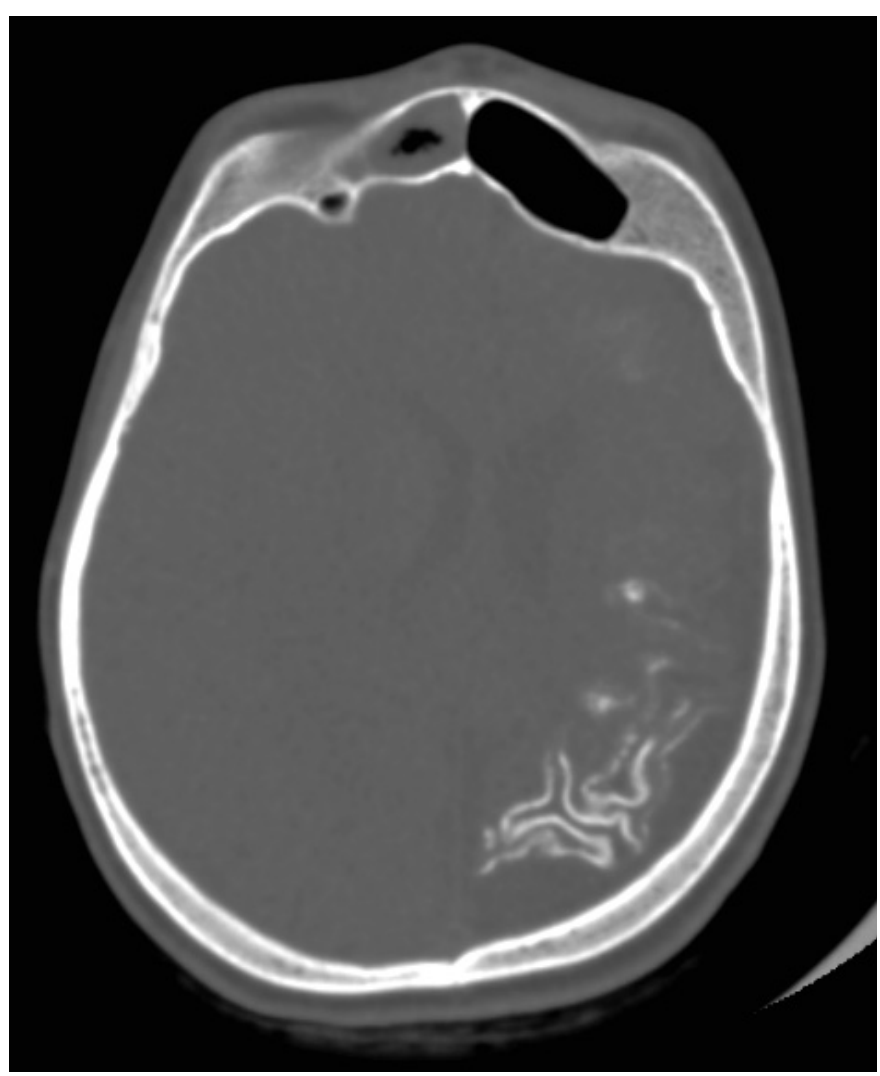

Fig. 15. The same.

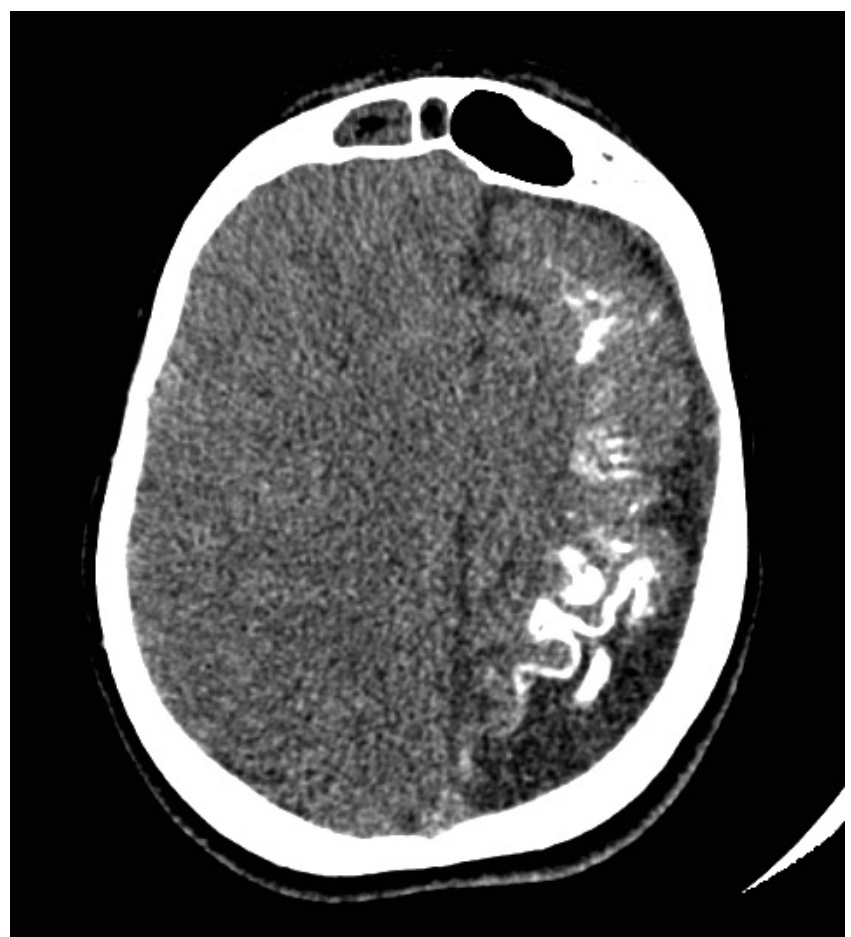

Fig. 16. Non-contrast brain CT. Asymmetry of the brain hemispheres with a decrease in the volume of the left and multiple areas of gyral calcification.

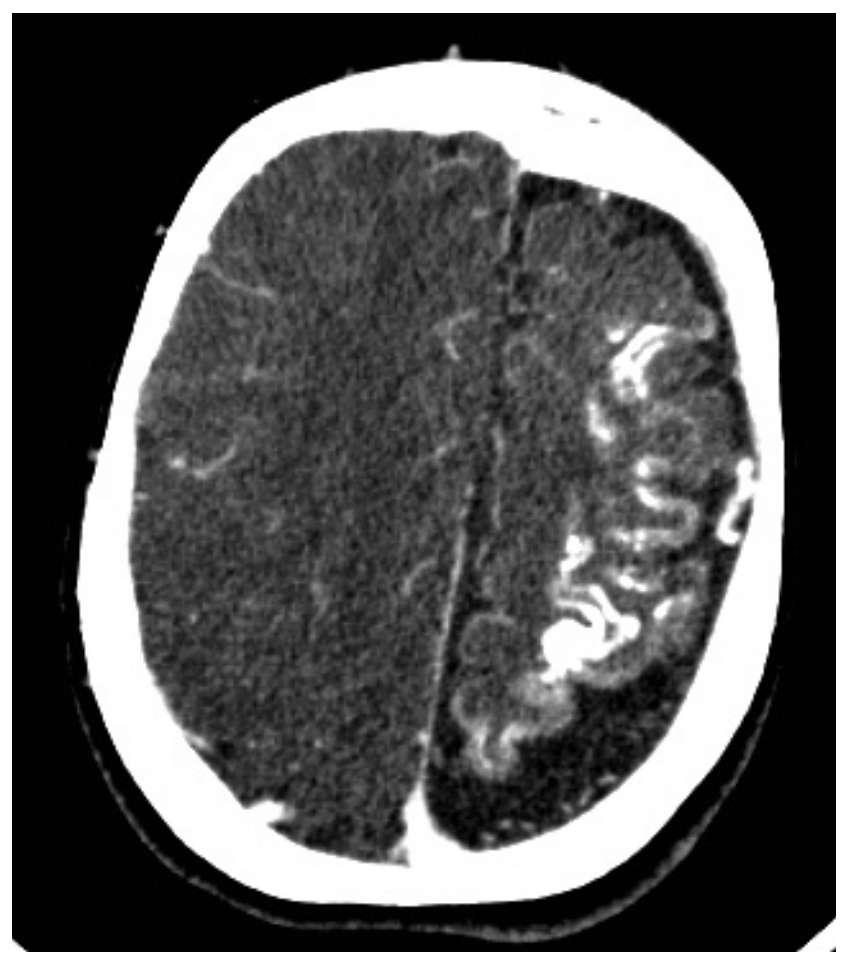

Fig. 17. Brain CT with contrast. Asymmetry of the brain hemispheres with a decrease in the volume of the left and multiple areas of gyral calcification. Leptomeningeal enhancement along the contour of the sulci and gyri on the left (as a manifestation of "pial angiomatosis"). 


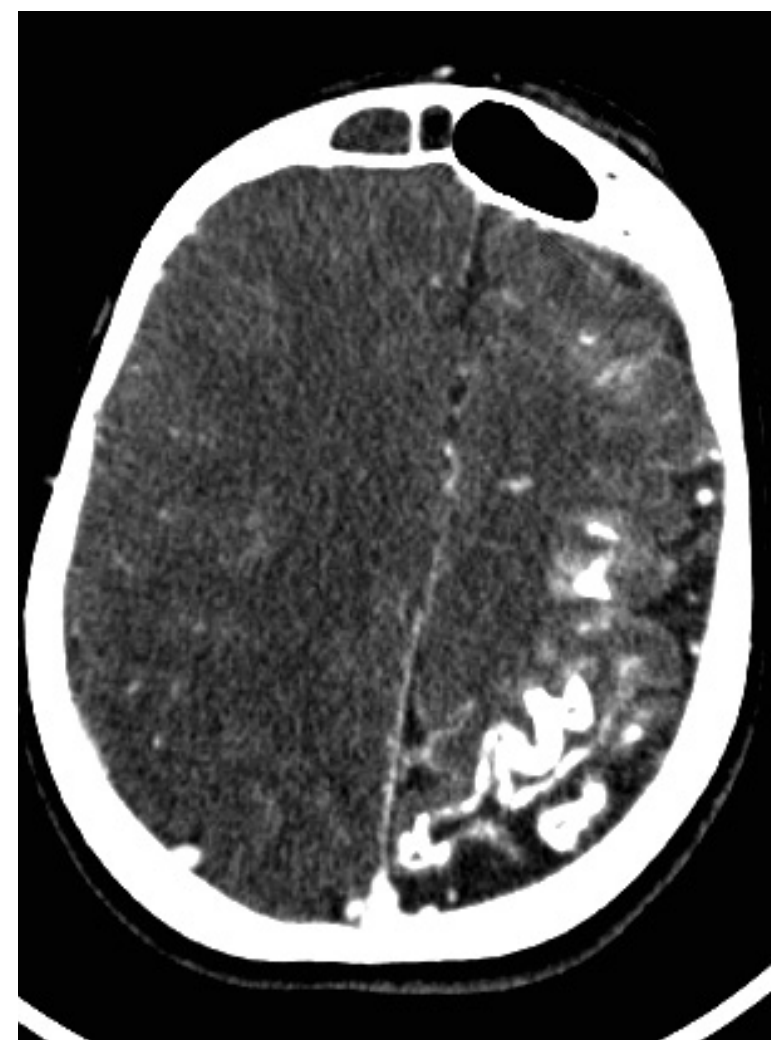

Fig. 18. The same.

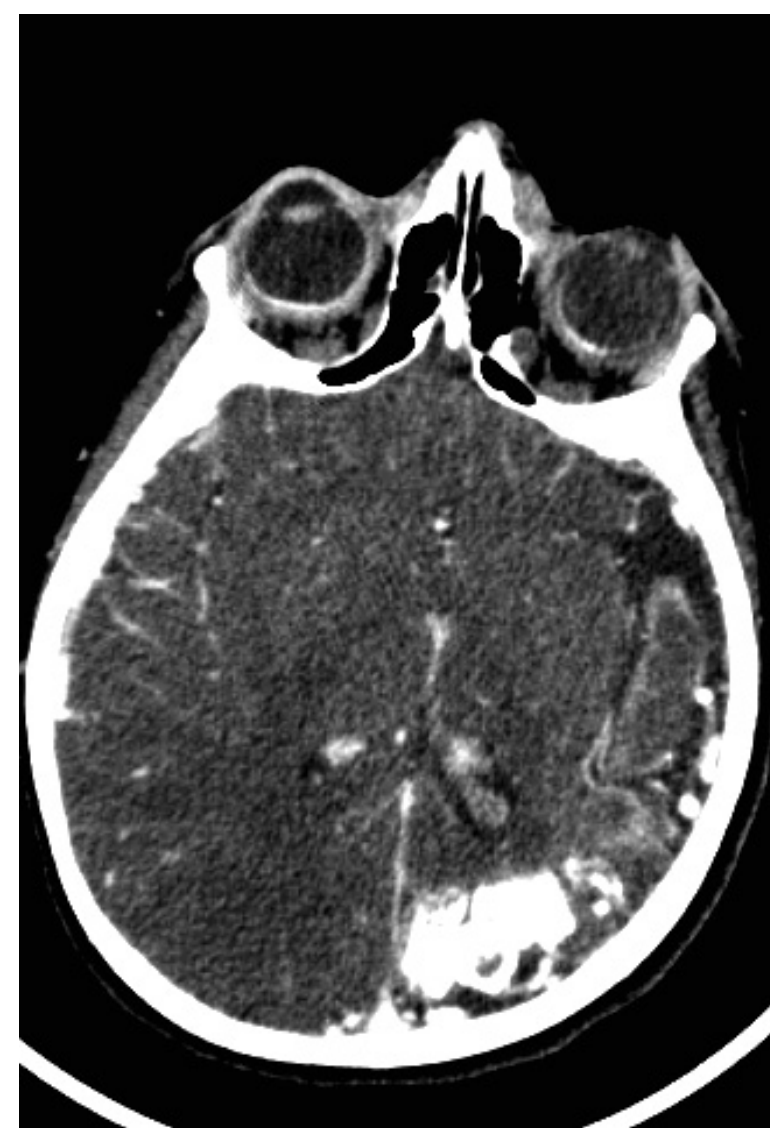

Fig. 19. The same. Asymmetry of the choroid plexuses of the lateral ventricles, bilateral choroidal angiomas.

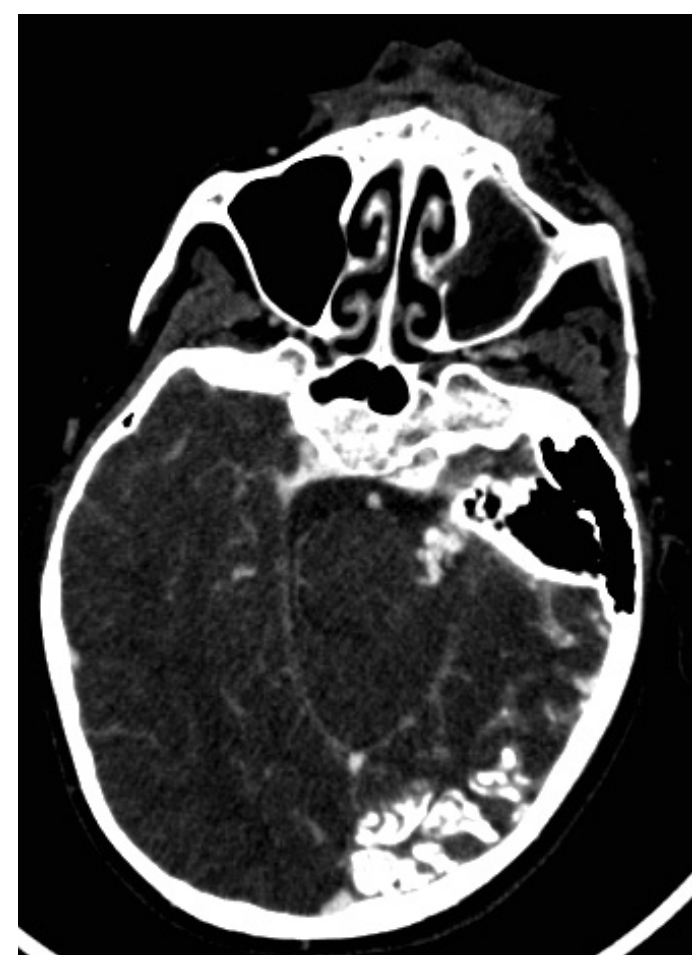

Fig. 20. Brain CT with contrast. Asymmetry of the brain hemispheres with a decrease in the volume of the left and multiple areas of gyral calcification. Leptomeningeal enhancement along the contour of the sulci and gyri on the left (as a manifestation of "pial angiomatosis") AVM in the region of the prepontine cistern on the left.

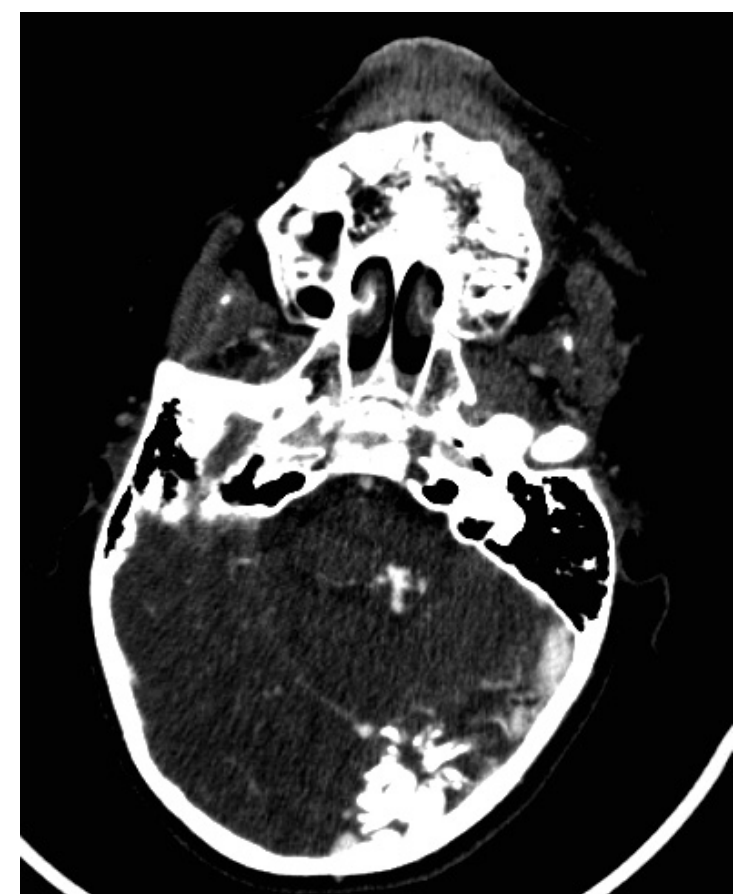

Fig. 21. Brain CT with contrast. Asymmetry of brain hemispheres with multiple areas of gyral calcification on the left. AVM of the left middle cerebellar peduncle. 


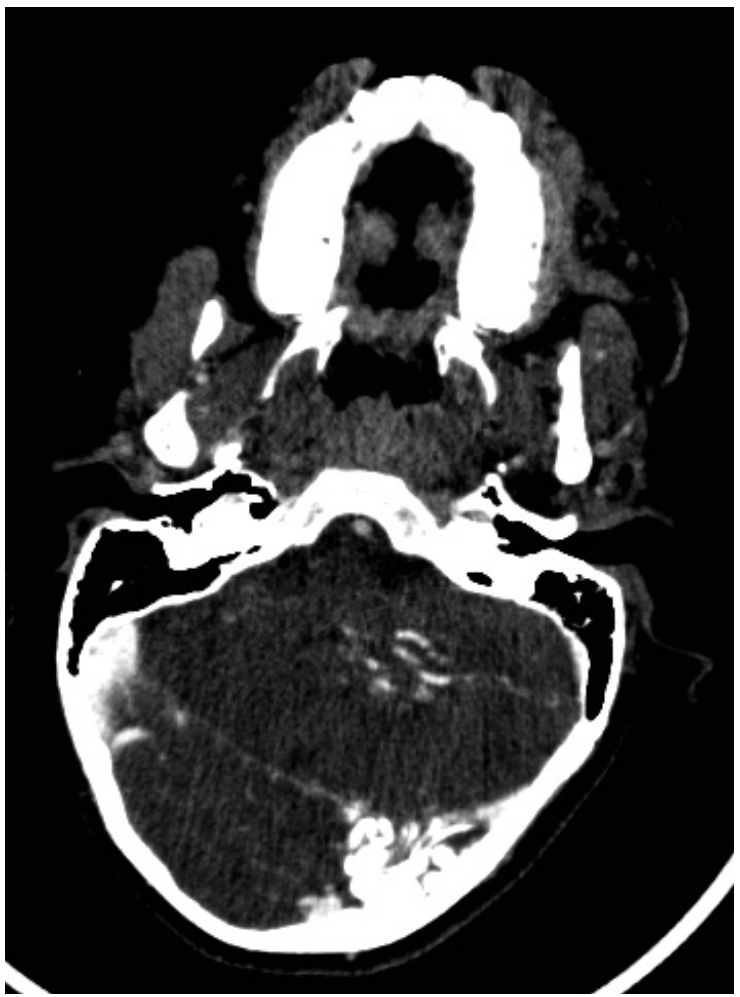

Fig. 22. Brain CT with contrast. AVM of the left middle cerebellar peduncle. Areas of gyral calcification in the left occipital lobe.

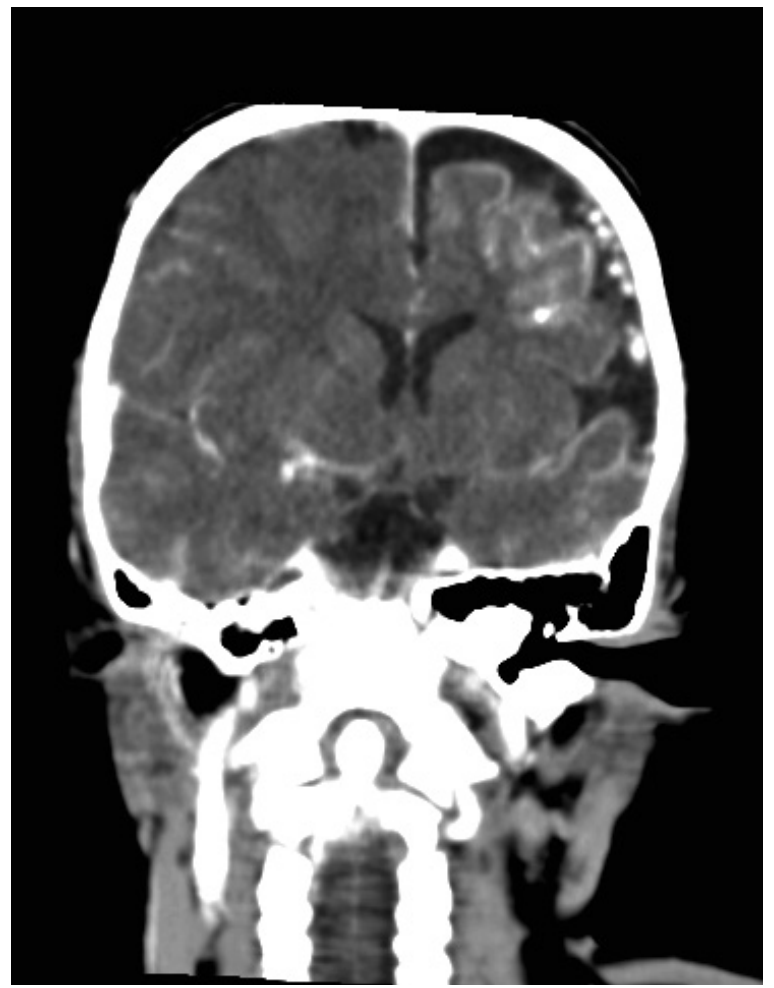

Fig. 23. Brain CT with contrast. Asymmetry of hemispheres of the brain with a decrease in the volume of the left hemisphere and leptomeningeal enhancement along the contour of the sulci and gyri (as a manifestation of "pial angiomatosis").

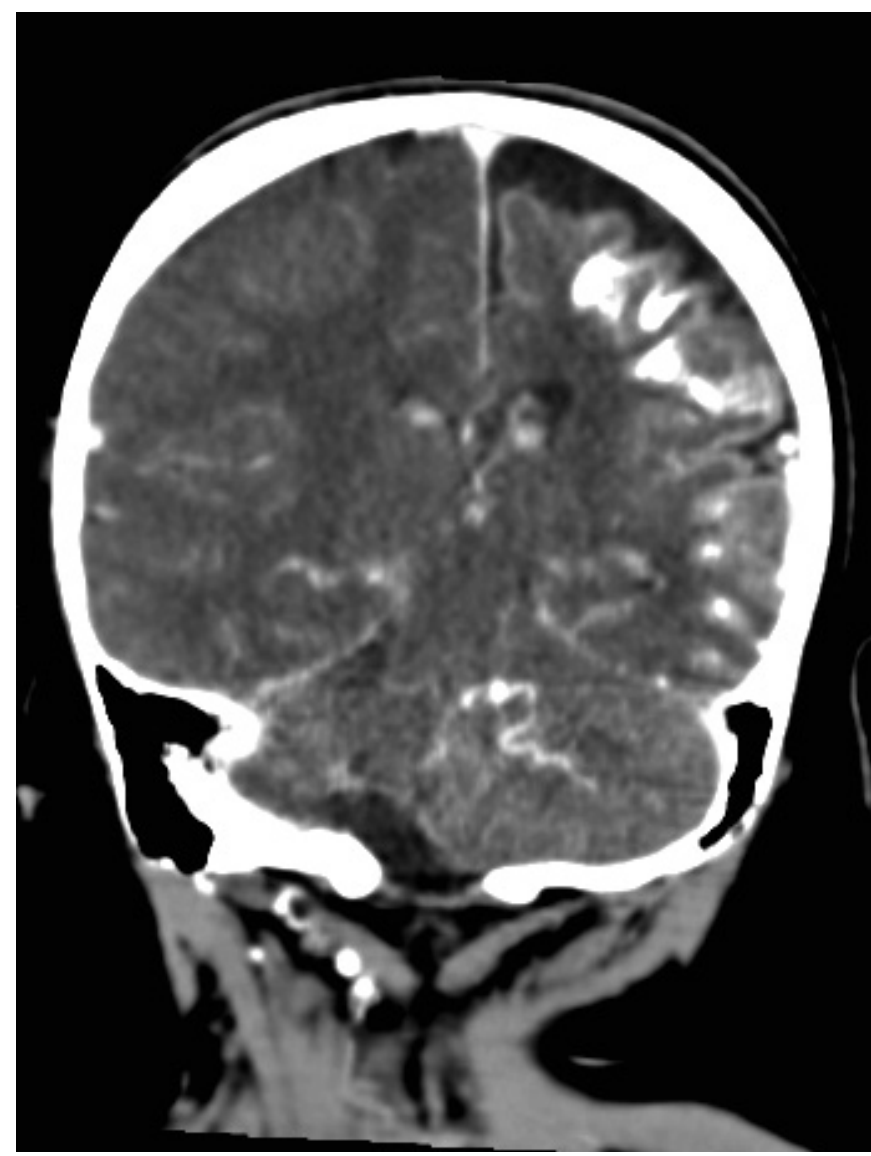

Fig. 24. Brain CT with contrast. Asymmetry of the brain hemispheres with a decrease in volume and areas of gyral calcification in the left hemisphere. Leptomeningeal enhancement along the contour of the sulci and gyri (as a manifestation of "pial angiomatosis"). AVM of the left middle cerebellar peduncle.

Perspectives. SWCS can be associated with tuberous sclerosis, hypomelanosis Ito, type I neurofibromatosis, nevus Ota, and pigmentovascular phakomatosis. Overlapping of SWCS and Klippel-Trenone syndrome features are often reported (by 2010, more than 40 such cases were described in the English-language literature). Therefore, a number of authors $[1,10,11]$ are in favor of their unification into an independent nosology under a common eponymous name: Sturge-Weber/Klippel-Trenone overlapping syndrome.

It is assumed that SWCS and Klippel-Trenone syndrome are one and the same disease with different manifestations, but should be considered different units $[10,11]$.

Conflict of interest information. The authors declare no conflict of interest related to the publication of this article. 


\section{Literature}

1. Елькин В. Д. Частная дерматоонкология. Часть II. Сосудистые опухоли и мальформации / В. Д. Елькин, Л. С. Митрюковский, Т. Г. Седова. - Пермь: ООО «Пермское книжное издательство», 2018. - 478 с.

2. Макомела Н. М. Идиопатическая симметричная энцефальная кальцификация / $\mathrm{H}$. М. Макомела // Променева діагностика, променева терапія. - 2010. - № 1. - С. 38-41.

3. Ткач В. В. Впервые выявленный синдром Штурге-Вебера-Краббе у беременной / В. В. Ткач, Ю. В. Бобрик, В. А. Пономарев // Таврический журнал психиатрии. - 2018. - № 2. - C.56-62.

4. Шевченко О. А. Енцефалотригемінальний ангіоматоз (синдром Стерджа-ВебераКраббе-Дімітрі). Випадок із клінічної практики / О. А. Шевченко // Перинатологія та педіатрія. - 2013. - № 4. - С. 25-28.

5. Early magnetic resonance imaging to detect presymptomatic leptomeningeal angioma in children with suspected Sturge-Weber syndrome / C. Bar, J. M. Pedespan, O. Boccara [ et al.] // Dev Med Child Neurol. - 2020. - Vol. 62(2). P. 227-233. https://doi.org/10.1111/dmcn.14253.

6. A rare case of retinal detachment with choroidal haemangioma associated with SturgeWeber syndrome mimicking Schwartz syndrome / V. Satyawali, G. Govindsinghtitiyal, V. Sharma [ et al.] //Journal of Evolution of Medical and Dental Sciences. - 2013. - Vol. 2, N 21. - P. 3710. https://doi.org/10.14260/jemds/752.

7. Godge P. Síndrome de Sturge Weber: um relato de caso. / P. Godge, S. Sharma, M. Yadav [et al.] // Rev. odonto ciênc. - 2011. - Vol.26, N4. - P. 366-369. https://doi.org/10.1590/S198065232011000400016.

8. Nakashima M. The somatic GNAQ mutation c.548G $>$ A (p.R183Q) is consistently found in Sturge-Weber syndrome / M. Nakashima, M. Miyajima, H. Sugano [ et al.] // J Hum Genet. - 2014. - Vol. 59. - P. 691-693. https://doi. org/10.1038/jhg.2014.95.

9. Nidhi C. Sturge-Weber Syndrome: An Unusual Case with Multisystem Manifestations / C. Nidhi, C. Anuj // Ethiop J Health Sci. - 2016. Vol. 26(2). - P. 187-192. https://doi.org/10.4314/ ejhs.v26i2.13.

10.Pereira de Godoy J.M. Dominant inheritance and intra-familial variations in the associa- tion of Sturge-Weber and Klippel-TreunaunayWeber syndromes / J. M. Pereira de Godoy, A. C. Fett-Conte // Indian J. Hum. Genet. - 2010. - Vol. 16(1). - 26-27. https://doi.org/10.4103/09716866.64943.

11. Sen S. Phakomatosis pigmento-vascularis presenting with Sturge-Weber syndrome and Klippel-Trenaunay syndrome / Sen S., Bala S., Halder C. [et al.] // Indian J. Dermatol. - 2015. - Vol. 60(1). - P. 77-79. https://doi. org/10.4103/0019-5154.147801.

12. Sturge W. A. A case of partial epilepsy, apparently due to a lesion of one of the vasomotor centres of the brain / W. A. Sturge // Transactions of the Clinical Society of London. -1879 . - N 12. - P. 162.

13. Sturge-Weber Syndrome and Port-Wine Stains Caused by Somatic Mutation in GNAQ / M. D. Shirley, H. Tang, C. J. Gallione [et al.] // N. Engl. J. Med. - 2013. - Vol. 368 (21). - P. 1971 1979. https://doi.org/10.1056/NEJMoa1213507.

14. Waelchli R. New vascular classification of port-wine stains: improving prediction of SturgeWeber risk / R. Waelchli, S.E. Aylett, K. Robinson [ et al.] // Br. J. Dermatol. - 2014. - Vol. 171(4). - P. 861-867. https://doi.org/10.1111/bjd.13203.

15. Weber F. P. Right-sided hemi-hypertrophy resulting from right-sided congenital spastic hemiplegia, with a morbid condition of the left side of the brain, revealed by radiograms / F. P. Weber // Journal of Neurology and Psychopathology (London). - 1922. - N 3. - P. 134-139. https://doi.org/10.1136/jnnp.s1-3.10.134.

\section{STURGE-WEBER-CRABBE SYNDROME}

\section{L.R. Zabudskaya, L.S. Vigovskaya, K.O. Ruzhylo}

Sturge-Weber-Crabbe syndrome (SWCS, encephalo-trigeminal angiomatosis) is a rare neurodermal disease (phacomatosis), characterized by vascular skin, eyes and brain abnormalities. The incidence is 1 for 50,000 and it is equal in women and men. All races and ethnic groups are affected without gender differences.

The history of the first descriptions of SWCS, its detailing, elements of etiopathogenesis and clinical description, aspects of the medical imaging technologies application in SWCS identifying are presented. 
As part of a clinical observation the brain CT and MRI results of the 9-year patient with SWCS are described and illustrated in details.

It is noted that patients with SWCS should be under the supervision of a multidisciplinary team (medical geneticist, dermatologist, neurologist, epileptologist, neurosurgeon, neuropsychologist, ophthalmologist, ophthalmosurgeon, vascular surgeon, neuroradiologist) with training in the diagnostics and treatment of hereditary neurodermal syndromes .

Keywords: Sturge-Weber-Crabbe syndrome, encephalo-trigeminal angiomatosis, phacomatosis.

\section{СИНДРОМ \\ СТЕРДЖА-ВЕБЕРА-КРАББЕ}

\section{Л.Р. Забудська,}

Л.С. Віговська, К.О. Ружило

Синдром Стерджа-Вебера-Краббе (ССВК, енцефало-тригемінальний ангіоматоз) рідкісне нейрокутанне захворювання (факоматоз), що характеризується судинними аномаліями шкіри, очей i мозку. Захворюваність становить 1 на 50000. Жінки і чоловіки хворіють однаково часто. Уражаються всі раси та етнічні групи без гендерних відмінностей.

Викладено історію перших описів ССВК i його деталізації, елементи етіопатогенезу i клініки, аспекти застосування технологій медичної візуалізації при ідентифікації ССВК.

В рамках клінічного спостереження хворої ССВК у віці 9 років детально описані і проілюстровані результати КТ і МРТ обстеження головного мозку.

Відзначено, що хворі ССВК повинні перебувати під наглядом мультидисциплінарної команди лікарів (медичний генетик, дерматолог, невролог, епілептолог, нейрохірург, нейропсихолог, офтальмолог, офтальмохірург, судинний хірург, нейрорадіолог), що мають підготовку в галузі діагностики і лікування спадкових нейрокутанних синдромів.

Ключові слова: Синдром Стерджа-ВебераКраббе, енцефало-тригемінальний ангіоматоз, факоматоз.

\section{СИНДРОМ СТЕРДЖА-ВЕБЕРА-КРАББЕ}

\author{
Л.Р. Забудская, \\ Л.С. Виговская, К.О. Ружило
}

Синдром Стерджа-Вебера-Краббе (ССВК, энцефало-тригеминальный ангиоматоз) редкое нейрокутанное заболевание (факоматоз), характеризующееся сосудистыми аномалиями кожи, глаз и мозга. Заболеваемость составляет 1 на 50000. Женщины и мужчины болеют одинаково часто. Поражаются все расы и этнические группы без гендерных различий.

Изложены история первых описаний ССВК и его детализации, элементы этиопатогенеза и клиники, аспекты применения технологий медицинской визуализации при идентификации ССВK.

В рамках клинического наблюдения больной ССВК в возрасте 9 лет подробно описаны и проиллюстрированы результаты КТ и МРТ обследования головного мозга.

Отмечено, что больные ССВК должны находиться под наблюдением мультидисциплинарной команды врачей (медицинский генетик, дерматолог, невролог, эпилептолог, нейрохирург, нейропсихолог, офтальмолог, офтальмохирург, сосудистый хирург, нейрорадиолог), имеющих подготовку в области диагностики и лечения наследственных нейрокутанных синдромов.

Ключевые слова: Синдром Стерджа-Вебера-Краббе, энцефало-тригеминальный ангиоматоз, факоматоз. 